\title{
The Study of the Human Resource Practice of Breakthrough Innovation and Micro-Innovation Based on the Theory of the AMO Model
}

\author{
Jing Bai, Weihao Wang \\ South China University of Technology, Guangzhou, China \\ Email:604476485@qq.com,908015593@qq.com
}

Received 18 May 2016; accepted 10 July 2016; published 13 July 2016

Copyright (C) 2016 by authors and Scientific Research Publishing Inc.

This work is licensed under the Creative Commons Attribution International License (CC BY). http://creativecommons.org/licenses/by/4.0/

(c) (i) Open Access

\begin{abstract}
Based on the Perspective Ability-Motion-Option model (Hereinafter referred to AMO) by innovative companies based human resource practice different strategies and business models adopted, in-depth analysis examines the strategies of enterprises-business model-organizational capacitythe path of human resources practices. This article will break through innovation of the Beijing Genomics Institute (Hereinafter referred to BGI) typical business representatives and Tencent micro-innovation strategy under the guidance of as a typical case study, theory and practice, it aims to HR practices to business strategy, business model and core competence analysis of a supporting role, for many innovative companies under the new normal background to provide practical reference.
\end{abstract}

Keywords

Breakthrough Innovation, Micro-Innovation, AMO Model

\section{Introduction}

Experience shows that the development of the Asian tigers, Developing Countries in the initial stage often imitates improved countries slavishly. Especially since 2011, the Chinese economy had entered a slow growth of the transition period of adjustment, GDP growth in the single digits entered the era. After the realization of economic take-off, companies will have to extend the industrial chain ends intrinsic motivation. Meanwhile, with the growing diversity of customer demand and the increasingly fierce market competition, technological innova- 
tion has become the enterprise survival and development of important resources. R \& D has become an important weapon for business success. Therefore, at this stage, enterprises need to carry out two types of innovations: on the one hand, it needs to be closely tracking the latest technology at home and abroad, in the absorption, to micro-innovation on the basis of imitation; on the other hand, it has a number of groundbreaking technologies involved, enhances the capability of independent innovation, and achieves breakthrough innovation.

Chinese high-performance businesses in the growth process, internal management and organizational capacity to play a central role. Enterprises should continue to grow, to get high performance, and must continue to polish their core competitiveness. In the period of rapid growth, Chinese companies gain a competitive advantage by taking the form of trade barriers franchise, government regulation and monopoly of resources [1]. But after entering the slow growth, relaxation, technology, and changes in government regulation of the market, greatly weaken the competitive enterprises in this regard. Because the company is required by the continued success of product innovation and speed to market, today's competitive advantage comes mainly from internal management and organizational skills, which is the core of an outstanding talent, and cultivates such talents Competitiveness is relying on implementation and enforcement of corporate human resources practices.

In this paper, in order to explore the implementation of innovative strategies to distinguish between different types of corporate human resources policies, it provides some human resources practices relevant companies learn. Therefore, this article will be implemented by the micro-enterprises and the implementation of innovative strategies to break through innovation strategy enterprise contrast, select BGI and Tencent, respectively, as a typical representative of the enterprise to conduct field research and interviews analysis, from corporate strategy, core competencies, and then human resource strategies to practice one by one analysis, which summarize the implementation of innovative strategies for different enterprises human resource practice characteristics, and provides a reference for the human resources practices breakthrough innovation and micro enterprises innovative enterprises.

\section{Theory Review}

\section{(1) innovative enterprises}

Innovative enterprises through the development and application of innovation, to provide customers with unique, a business model high value-added products [2]. Innovative companies focus on product innovation and customer value to bring more attention to the power of innovation, focus on the development of unique and sophisticated products. It has a unique product with high added value and timeliness of innovative features.

Breakthrough innovation strategy adopted by enterprises is a disruptive innovation, it has two levels, one is the low-end market or subversion of the original customer base carried out; the other is new in the new markets, new customers conducted market subversion. Breakthrough innovation and the use of existing knowledge is almost completely new knowledge, core competencies of both destruction and the role of alternative, often can open new markets and potential applications (Dewar, Dutton, 1984; Tushman, Anderson.1986) [3]. Richard Leifer defined breakthrough innovation must meet one of three conditions: new product features; improving the existing functionality of indicators at least 5 times; product costs significantly lower (at least 30\%) [4].

Micro-innovation adding new markets and customer understanding, and understanding this transformation to innovation go, then continued rapid iterative update. Innovation and value creation, nearly $98 \%$ is not the innovators but imitators have obtained (Oudi De • First Card, 2010) [5]. Liang Jun (2013) proposed the current business model of micro Innovation Strategy: mainstream compatibility micro-innovation form the core competitiveness will be the mainstream technology and mainstream consumer trends to create an eclectic masterpiece lead times; strategic breakthrough of micro-innovation; accumulated value of micro-innovation in certain areas of expertise continued accumulation of tiny products to achieve the ultimate formation of a new rival in a short time is difficult to break through the barriers of value; customer perception of micro-innovation for customers to directly experience and feelings [6].

\section{(2) organizational skills}

Different companies have different business strategies, different business strategies require different organizational capacity. Organizational capacity of the structure, mechanisms and systems set up for the implementation of the company's business strategy. Goal is to foster the development of organizational capacity difficult for competitors to imitate the unique ability to win the sustained competitive advantage. Innovative requires constant innovation and core competencies, in order to maintain the leading status of the products and services. 3M 
company requires each business unit must have an annual revenue of 30\% from new products, the company constantly innovate in order to maintain vitality [7].

Enterprises will have a breakthrough innovation capability in order to meet the needs of new customers and markets, offer new products and create new markets and develop new distribution channels. Existing products, services or technologies to be reformed, so that an innovative type these mainstream product/service design and technology to be eliminated (Chandy \& Tellis, 2000) [8]. Therefore, the definition of breakthrough innovation capability is now able to some products and services have an important transformation and innovation capability (Subramaniam \& Youndt, 2005) [9].

Micro-innovation capability enables enterprises to improve capacity, the use of existing knowledge and will focus on the scope of the existing market to strengthen existing skills and processes (Lewin et al., 1999) [10]. The ability to focus on small and micro-innovation, close to user needs; fast attack, trial and error. Micro-innovation is the core idea. User-centric, innovative models through the consumer experience the depth of excavation carried out. User-based roots, others will ignore the usual places where no multiple zoom, focus, allowing users to move into a selling point. Micro-innovation to grasp four points: from a humble place, giant did not see or look down on the place started, hit the edge of war and flanking warfare, away from the mainstream market, to enter the emerging market; second, multi-point trial and error, the lowest cost The minimum scale, rapid trial and error; Third, we must focus on a single point, identify the location, duration gather, extremely focused, to achieve the ultimate; 4 to detonate a single point [11].

\section{(3) AMO model}

Chinese high-performance businesses human resource practices play a role in the way, on the one hand by "AMO model" to build organizational capacity to gain a competitive advantage; on the other hand concern human resources strategic cooperation and participation [12]. Compared to the attention of human resources for systematic, attention match of human resources and corporate strategy have a greater impact on business performance. Different businesses require different business strategies organizational skills, it requires a different organizational structure to support the company's development and respond to the external environment. "AMO model" to undertake the core competence theory, emphasizing the focus strategy, simplifying management; pay attention to build core capabilities through a unique organizational ability to obtain sustainable competitive advantage; business-management-driven staff management, the limited HR resources trafficking in key sectors on [13].

"AMO Model” will be the business model, organizational capacity and management staff three key factors in the integration of the "planning" and "implementation" of the two chains, and form a continuous improvement cycle [14]. "AMO model" design logic, the definition of business management staff management [15]. "AMO model" execution logic is driven staff management business management [16]. Organizational skills embodied in employee motivation, staff capacity and staff assisted in three aspects, companies can build "AMO model" to join business objectives and employee management strategy to ensure that the strategic direction of the organization, processes, personnel and corporate coherence [17] (Figure 1).

"AMO model" is the three-dimensional model from staff capacity, power and power consisting of their unique ability to interact to form the organization, driving the company's continued success [18]. Organizational capacity to build including staff capacity, motivation and help the three aspects, dynamics and power are figuring out how to stimulate the enthusiasm of the staff issues, "dynamic" means to meet the needs of physiological and psychological to stimulate the enthusiasm of the staff, and the "power "it means to meet the needs of job autonomy to inspire enthusiasm [19]. The ability to manage staff recruitment and training need to be clear. Businesses often use transactional incentives and affective excitation of these two different motives incentive policies to stimulate two different employee motivation-extrinsic motivation and intrinsic motivation [20]. Organizational structure and communication mechanisms are the two pillars of the platform staff booster, the combined effect of the staff for their importance in the organization of perception [21].

"AMO model" has three core ideas: First, human resource management to drive corporate performance by employees "three forces" [22]. Secondly, the six elements of human resource management, can effectively improve staff "three forces." Third, human resource practices through "three forces" in order to affect the company's performance [23] (Figure 2).

At present, for innovative human resource practices study comparing saturated, Ma Meiying (2007) based on the current lack of innovative enterprises innovative distribution mechanism [24], the core culture of innovation, risk 

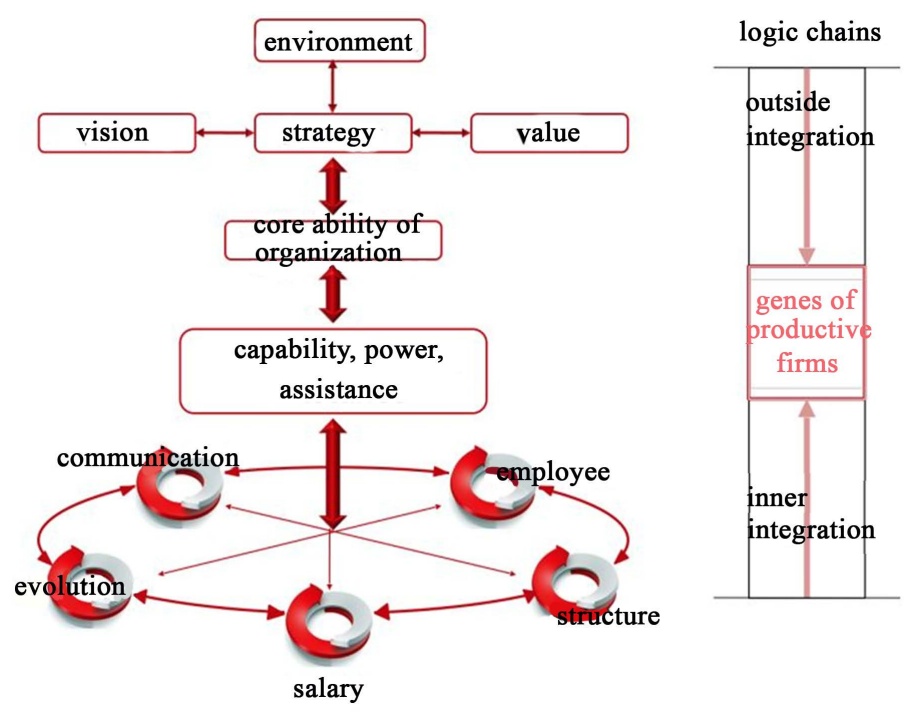

Figure 1. HR-driven business model diagram.

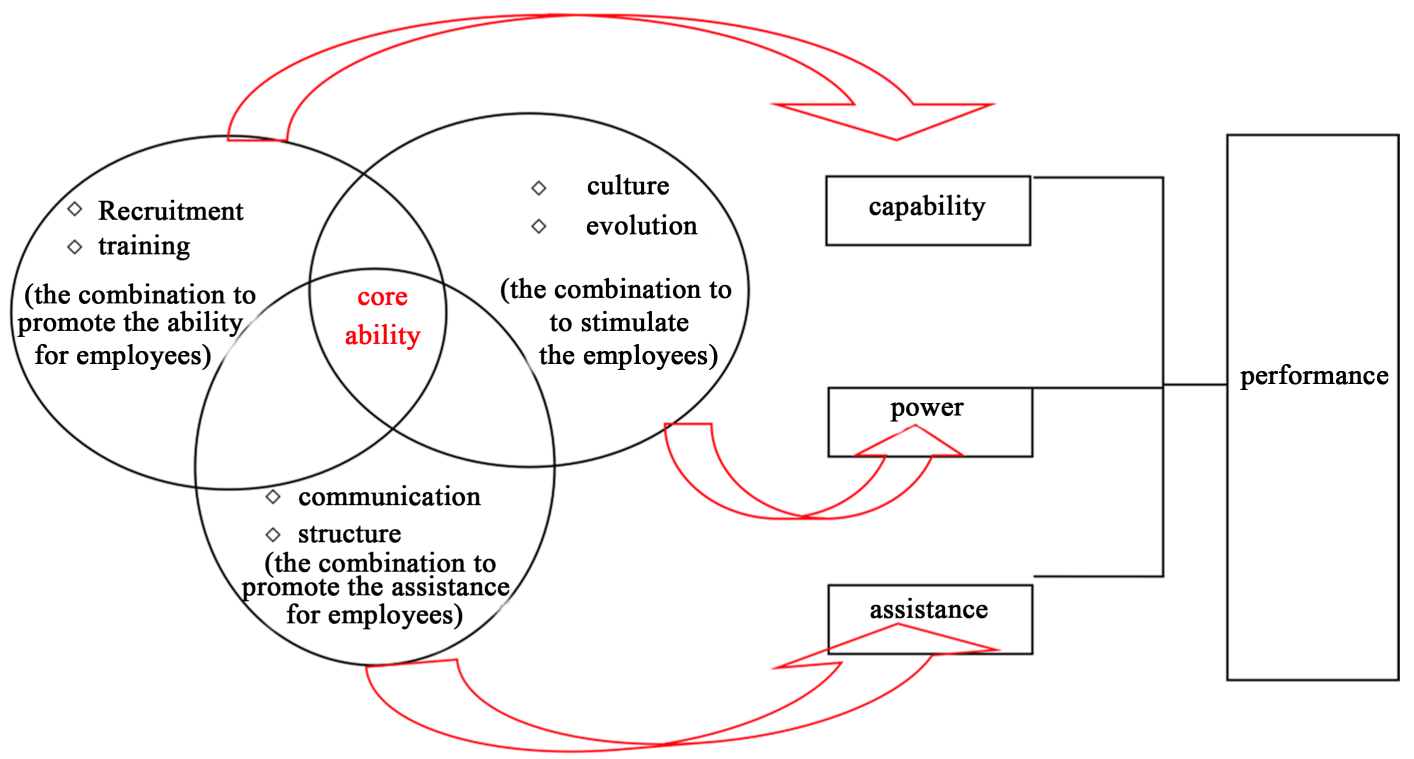

Figure 2. Drive corporate performance.

prevention system and innovative environment, human resource practices proposed to establish a competitive pay system, inclusive corporate culture, to provide adequate training and development opportunities, and create a pleasant work environment exciting, construction entrepreneurs for innovation [25]. Xugao Hua (2013) proposed to establish a new type of employee relations, to meet the needs of employees [26]; focus on the value chain, expand the scope of management; focus on knowledge workers, knowledge management; attract and retain talent, develop employees; the use of information technology, virtualization management; the development of enterprise capabilities, promote “people-oriented” values [27]. Emphasis on staff training and internal promotion system; train specialized personnel; the implementation of the power and ability to combine the pay system and job promotion system [28].

\section{Target Case}

Shenzhen rising paper chooses two companies for the study: Genomics and Shenzhen Tencent Computer System Co., Ltd. as the target case. BGI is rare in our country to achieve breakthrough innovation business repre- 
sentatives, and Tencent micro-innovation strategy success model [29]. Yin (2003) emphasized that the case studies to select a typical and extreme case was more appropriate. From the development process of the two companies and their organizations to provide support in terms of the ability to also meet the "typical case study to use visible" requirement Yin (2003) proposed.

\section{(1) A breakthrough innovation business representatives-BGI}

September 9, 1999, as the international Human Genome Project, "part of China” was officially launched, BGI was formally established in Beijing. Since the establishment of BGI establishs a large-scale sequencing, bioinformatics, health, agriculture and breeding, animal cloning, environmental microbiology technology platform, its sequencing capabilities and the world's leading genome analysis capability. 2007 Love Big gene seizes new opportunities for technological breakthroughs, we established the Beijing Genomics Institute Shenzhen, and Hong Kong have set up Mandarin, Mandarin America, Europe and Japan and China Mandarin and large branches, operations throughout the world. BGI through the "integration of industry" breakthrough innovation, research and development with industry to conduct research and promote interdisciplinary cross-industry integration and innovation, is gradually build biological field "Google".

In projects with industry, innovation and survival, cooperation and development "and" old "research institutions. Set production, learning and research as a whole, in order to research with production to production to support research, practice education, and scientific discovery, technology invention, tricyclic interactive industry, for their own leaps and bounds laid the cornerstone. as a nonprofit research institution, BGI in enterprise mode of operation, to create a unique "three rounds of three zones" linkage model and superior education people mechanism innovation worldwide reputation.

\section{New business model: research integration}

With the rapid development of China's industry gene, the gene sequencing to clinical research, industry chain gradually complete the upgrade, but still far from the "Red Sea" phase, mixed companies in the industry. BGI sharp smell of the opportunities and prospects of gene sequencing, gene start drawing industry contacts map. At the same time, combined with the integration of production and research development cycle, the new business model is applied to the practice of gene industry. March 2013, the acquisition of the American Society of Gene BGI detector company Complete Genomics, has since self-control hardware platform. In the leading technology platform, to seek a breakthrough on the sequencing of content, realize the combination of innovation and research, and business support research to promote production research.

\section{Biological "Google” breakthrough innovation capability}

BGI has been published since its inception in 1999 due to the international academic journals Articles 597, SCI included 549, the establishment of large-scale sequencing, bioinformatics, health, agriculture and breeding, animal cloning technology platform, and its sequencing capabilities Genome analysis capabilities of the world's leading, proved to the world its scientific, academic, industry independent innovation ability and the feasibility of the integration model. BGI mainly clear vision of positioning, integration and interdisciplinary research on cross force formed its own unique competitiveness.

Today, Mandarin annual income three times the rate of rapid growth in 2007 revenue Love Big gene annual rate of 3 times in rapid growth, 200 annual income of more than 400 million yuan in 2010 exceeded 10 billion, of which about half revenue comes from cooperation with foreign academic institutions. This is one of the secret weapons they were derived from the integration of domestic and foreign scientific and technological resources, good at mining and use of innovative young talents. In the academic qualifications for the research on the atmosphere, uncharacteristically not only academic, and even high school students give up the entrance reuse Zhao Bowen. Moreover, the daily work is often rewarded unconventional behavior, establishment of a free schedule of university-style entrepreneurial team, this is the scientists and innovators of respect and encouragement. Flat architecture and accessibility of the cubicle so that unimpeded exchange and sharing, there is no rank tied for innovation to create "hotbed".

\section{Paranoid innovation}

BGI to "interpret the mystery of life, and write industry chapter", the mission to attract and motivate employees, with the confidence of genetic engineering, Wang Jian said genetically engineered so that every Chinese people "not hungry not stupid disease is not the old" China dreams will gradually be achieved. His eclectic use of innovative talents, and innovation research team working intimate, personally saw a staff scientist for innovation and leadership respect and paranoia. Thereby creating a BGI innovative pioneer culture.

Hua large conference room one wall, marked with the full published in "science", "nature" paper, which is the vast majority of research institutions and universities are unmatched. In Mandarin, the scientists are not only of 
scientific research "nerd", as they like in college, I research the extension of his interest in the UW community hobby, simple and harmonious atmosphere for innovation cultivate a "a vanguard of innovation".

\section{Unique human resources strategy: Talent joint training}

BGI was able to create new business models and breakthrough innovation capacity and research integration largely depends on its scientific talent to support joint training of the new mechanism. Over the years, BGI has signed with Shenzhen University, South China University of Technology, Wuhan University, Southeast University, University of Electronic Science and Technology, Huazhong University of Science and Technology as well as an agreement to carry out joint training of personnel, "the project with discipline, with industry, with talent" emphasizing personnel training in actual combat. At the same time, also with the University of Copenhagen, Aarhus University and the Chinese University of Hong Kong signed a doctorate or master's joint training agreement to carry out joint training of students. Genome Sciences to fit large scientific, comprehensive and cross-cutting-edge features, BGI proposed in the framework of the existing education system and universities, and research to explore new teaching model in line with the development of genome science, its innovative $2+$ $2+\mathrm{X}$ students of full-time and made "Genomics Institute" is an example. Allegedly, BGI has nearly 5, 00 employees, the equivalent of a medium-sized university, with more than 1000 professionals in the field of bioinformatics have different professional backgrounds, these people exactly Mandarin breakthrough innovation engine.

\section{Flexible project team management system}

BGI adopt a flexible project management team, Young Bo Zhaowen graduated from high school not because of its superior ability to innovate and research strength alone to lead a research team developed a problem. In Mandarin, there are many such issues R \& D team, their flexibility to operate production and research integration. UW young people can find their own areas of interest, you can also take the initiative to apply for any project. Genomics Research Institute established a technical development team were covering all the range of BGI field research project for the study of the underlying core technology development, research trends and gather the world's latest technology research, and then provided to the Institute to practice. Initially composed of 10 individuals, and now they began to follow the field, it is longitudinally divided into different platforms team for the new project before the project can give a reasonable, professional judgment and advice, so that innovative ideas can be more quickly and efficiently get a response within. The project team from time to time there will be interim progress targets, progress in the middle stage will be given to minor reward. Meanwhile, the project team will often organize project will promote the exchange of experiences and better development of the project.

(2) micro-enterprise innovation representatives-Tencent

Tencent was founded in 1998, headquartered in Shenzhen, one of China's largest Internet service provider, is also China service user one of the largest Internet companies. The company's main products are Tencent IM software, online games, portals, and related value-added products. According to the survey data iResearch show that in 2003, Tencent QQ in the Chinese market share is 74.3\%. 2004 Tencent went public on the Hong Kong Stock Exchange Main Board. 2013 consolidated monthly active accounts WeChat and WeChat reached 355 million, instant messaging services monthly active accounts reached 808 million, instant messaging service peak concurrent online account number to reach 180 million, "QQ space” monthly active accounts reached 625 million. 2013, Tencent total market capitalization of 100.6 billion US dollars, China’s market capitalization topped \$ 100 billion mark for Internet companies. April 2014, Tencent QQ simultaneous online user accounts exceeded 200 million, to achieve annual growth of 4100 million.

\section{Imitation ahead, beyond innovation}

Tencent "user experience, fast iteration" strategy based on imitation ahead, beyond innovation, sitting on massive user, delicate user experience with seamless links to research, build massive user direct interaction with the product manager of product support platform.

Many companies in the Internet sector faint smell Tencent, Tencent because the company's products once they are spotted, it is doomed to perish. Tencent imitation genetic origin QQ, microblogging after, anti-virus software, e-commerce to the micro-channel, are imitating rival products, but on top of this product and application innovation, thereby obtaining an excellent user experience, far more than rivals until thoroughly opponent out of competition in the market. In particular, we know it is in Tencent micro letter to dig millet meters language chat product added, shake, sweep the social function of the depth of excavation after the launch of weak ties, which go beyond the imitative innovation effort had staggering. 2013, Tencent total market capitalization of 
100.6 billion US dollars, China’s market capitalization topped \$ 100 billion mark for Internet companies. April 2014, Tencent QQ simultaneous online user accounts exceeded 200 million, to achieve annual growth of 4100 million.

\section{Seamless user experience and $\mathrm{R} \& \mathrm{D}$}

Tencent based on their user stickiness has formed its own micro-innovation capability, build massive user direct interaction with the product manager of product support platform. Founded in 2007 Tencent Institute of "micro-innovation" reward, but was full ownership. Focus on the creative thinking selection related to smartdegree and user feedback associated data analysis capabilities, and in the performance appraisal is more focused and result-oriented innovations associated evaluation, so that all departments wholeheartedly participate in the user experience the ultimate.

\section{Happy vibrant university}

Tencent CEO Ma requires that each middle management for their "backup" assistant, the senior team is also there has been such a pairing mode. His amazing ability to learn, but also willing to listen to people with different perspectives, which also makes Tencent brainstorming session vote on professional and impartial. This intense learning ability persistent infection with staff time, and then sketched out an imitation innovation beauties. Tencent adhere to the "customer first" philosophy, from the creation of user value, social value angle and thus enhance corporate value, attention to employee benefits stimulate potential employees, and employees to grow together. Under the guidance of this concept, Tencent hope to use by providing Internet services to enhance the quality of people's lives, the Internet industry to make water and electricity, for creating a culture of "happy energetic university", so that employees active application in a relaxed atmosphere innovation, always will enhance the user experience requirements to keep in mind.

For expanding staff size, staff development and whether the industry and the company's development simultaneously is an urgent problem, the company's solutions rely mainly on road culture-cultural management committee set up to promote corporate values, to accelerate the integration of new companies pace. Tencent as the staff for the first Fortune companies, Tencent services and capital is not the most important, most people are not easily replaced, is the most valuable asset.

\section{Unique human resource strategy: independent team building}

In 2012, to conform to user needs and drive business development, Tencent organizational restructuring, the original system upgrade business systems become customer-oriented business group system. "All customer value in mind" business philosophy, Tencent architecture adjustment, once again highlighted, Tencent efforts to build customer-centric business units, this vertical structure is more conducive to the development of independent project team. Tencent, each large project team Division of nested inside a small team, the project team staff are given full authorization. Tencent each business group is gradually becoming a "strengthening the core platform ++ key business focus to support industry chain partners", the organic structure, to further promote the industry ecosystem to achieve win-win opening up, its flexible architecture independent team in the ecological pattern opening win will play a huge role in shaping and strengthening innovation capabilities.

\section{Conclusions and Implications}

Innovative business strategies of enterprises need like thinking people (love of innovation, the pursuit of novelty), and should be used on organizational policy matrix organizational structure, the implementation welcomed by customers of new products through a highly authorized project team. On a business process, you must with excellent product development and product launch processes, development of new products with unique features, and quickly promote their products to market.

Innovative enterprise business strategy requires creative employees, and employees need to provide comfort, freedom and relaxed working environment. Therefore, innovative organizational structure should be flexible and changeable, flat organizational structure more suitable for such enterprises. According to our team goal of enterprise case study analysis, innovative enterprises induction study can be summed up human resource practices and organizational capacity this capacity necessary for their requirements based on innovative companies adopted different strategies and business models.

\section{A breakthrough innovation of the human resources strategy}

Recruiting and developing breakthrough innovation Talents

(1) Personnel recruitment innovative gene 
In the recruitment before strict control, by building a model to create a new job, the way of selecting talent is the real innovation.

(2) Focus on joint training of personnel

It promotes research integration model "task with scientific, industrial zone, with talent", the development of joint training through innovative mechanisms, in particular the establishment of joint training BGI-oriented system and universities, by this way continue to provide a large talent pool, China building blocks.

Focus on long-term incentives, team evaluation and reward

Approved by the way to advocate and pay attention to internal motivation, so as to better encourage innovative team BGI encourages long-term innovation project team performance oriented, and focuses on long-term business results-oriented team incentives, while giving its full recognition of the material and spiritual incentives.

Cultivation breakthrough innovation culture

Culture is one of the genes engraved in the bones; BGI emphasizes projects with talent in culture, with eclectic talent, given the opportunity to participate or personnel responsible for the project, the opportunity to make these innovative talents better in the project learning culture breakthrough innovation culture.

Design-driven innovation work

(1) Full and innovative work environment

Staff provides such a work environment: simple atmosphere of interpersonal relationship, loose management form, with abundant resources, set up a simple organizational structure, so as to promote the communication between employees and exclude the interference of all kinds of management systems and organizational activities, so that the staff full heart and soul into innovation.

(2) Information sharing mechanism and open the project team collaboration system

Through the construction of the project team and establish an information sharing mechanism, these mechanisms of openness and cooperation can promote the flow of knowledge and information among employees, which can improve the work efficiency of communication and enhance the probability of creativity and inspiration.

Imitative innovation HR strategy

\section{Staff capacity selection, training and promotion under user guide}

Focusing on micro grasp of user awareness and innovative thinking on personnel selection, personnel training insists on the user guide, listens to the user's voice, and tends to micro-innovation promotion on performance output, three-pronged training staff good micro-innovation thinking and ability to do the front-end talent to control.

Results-oriented performance micro-innovation associated with recognition and incentive to jointly creates a comprehensive full micro-innovation culture.

Micro-innovation enterprises emphasize innovative user-oriented applications, it can be associated with the implementation of micro-innovation results-oriented assessment of no commercial sector earnings pressure, no pressure KPI assessment, will make these sectors more attention to the user experience, the product to achieve the ultimate. As for the daily work of employees in small and innovative, the project team access to the user good reputation of micro product design, and so should be timely to give full recognition incentives, enhance employee confidence in micro-innovation, which foster the full micro-innovation culture.

\section{Agile project management practice team made accelerated iterative update}

Innovative micro enterprises must establish a relatively soft and flexible organizational structure, agile project management portion of the system is the ideal choice. Innovation ability of an individual is narrow, the project team prepared to give full play the advantages of group members, to carry out research and development complementary creation, while improving management by the agile iteration rate. R \& D team of core research and development team and marketing staff will be well versed in the needs of the customer, based on the development of accurate user experience, excellent products give users a surprise.

Open sharing customers and employees to participate in the Innovation Ecosystem: Job Design

Businesses can improve by providing support to staff knowledge and information about their areas of interest related to certain employees' knowledge stickiness “to increase interdisciplinary cooperation of employees Innovation Team, to develop cross-border innovation paid off. Innovative micro enterprises can establish a dedicated in-house information sharing and access channels, extensive collection of customer needs and feedback of these issues to people from different professions and regions there. At the same time due to the great vitality of micro-innovation "grassroots economy", that is, front-line employees grasp market and customer needs tend to be more thorough than the manager, so good at micro enterprises to explore innovation and the importance of 
knowledge, innovation staff initiative, given its full discretion, to create incentives from the full recognition of the learning organization atmosphere.

\section{References}

[1] Lepak, D.P. and Snell, S.A. (2002) Examining the Human Resource Architecture: The Relationships among Human Capital, Employment, and Human Resource Configurations. Journal of Management, 28, 517-543.

[2] Collins, C.J. and Smith, K.G. (2006) Knowledge Exchange and Combination: The Role of Human Resource Practices in the Performance of high-Technology Firms. Academy of Management Journal, 49, 544-560.

[3] Chandy, R.K. and Tellis, G.J. (2000) The Incumbent's Curse? Incumbency, Radical Product Innovation. Journal of Marketing, 64, 1-17. http://dx.doi.org/10.1509/jmkg.64.3.1.18033

[4] Gatignon, H., Tushman, M.L., Smith, W., et al. (2004) A Structural Approach to Assessing Innovation: Construct Development of Innovation Locus, Type and Characteristics. Management Science, 48, 1103-1123. http://dx.doi.org/10.1287/mnsc.48.9.1103.174

[5] Subramaniam, M. and Youndt, M.A. (2005) The Influence of Intellectual Capital on the Types of Innovative Capabilities. Academy of Management Journal, 48(, 450-463. http://dx.doi.org/10.5465/AMJ.2005.17407911

[6] Mitchell, G.R. (2000) Industrial R\&D Strategy for the Early 21st Century Research. Tedznology Management, 43, 3135.

[7] Teece, D.J. (1998) Capluring Vahxefmn Knowledge Asset. The New Econany Market for Know-How and Intangible Assets. California Management Review, 40, 55-79.

[8] Merrifie, U.D.B. (2000) Changing Nature of Competitive Advantage Research. Tedznology Management, 43, 41-45.

[9] Christensen, C.M. and Bower, J.L. (1996) Customer Power, Strategic Investment and the Failure of Leading Firms. Strategic Management Journal, 17, 197-218.

[10] Danneels, E. (2002) The Dynamics of Product Innovation and Firm Competences. Strategic Management Journal, 23, 1095-1121. http://dx.doi.org/10.1002/smj.275

[11] Danneels, E. (2004) Disruptive Technology Reconsidered a Critique and Research Agenda. Journal of Product lnnovation Management, 21, 246-258.

[12] Jansen, J.J.P., Van Den Bosch, F.A.J. and Volberda, H.W. (2006) Exploratory Innovation, Exploitative Innovation, and Performance: Effects of Organizational Antecedents and Environmental Moderators. Management Science, 52, 16611674. http://dx.doi.org/10.1287/mnsc.1060.0576

[13] Lewin, A.Y., Long, C.P. and Caroll, T.N. (1999) The Coevolution of New Organizational Forms. Organization Science, 10, 535-550. http://dx.doi.org/10.1287/orsc.10.5.535

[14] Narver, J.C., Slater, S.F. and MacLachlan, D.L. (2004) Responsive and Proactive Market Orientation and New-Product Success. Journal of Product Innovation Management, 21, 334-347. http://dx.doi.org/10.1111/j.0737-6782.2004.00086.x

[15] Chen, C. and Liu Z. (2010) The Primary Methods of Case Study_Abstracts. Management Cases and Criticism, 175182.

[16] Liu, S. and Wang, W. (2011) The Formation of HR Practice Based on the Simulation Innovation Strategy—Based on the Case Study of the Tencent Computer System Company. Management Study, 4-8.

[17] Ma, M. (2007) HR Development and Management of Innovative Cooperation. Science and Company, 47-50.

[18] Sun, R.X. (2013) The Core Competitiveness Promotion Propelled by Micro Innovations. Academic Communication, 127-130.

[19] Wang, H., Fan, L. and Zhang, W. (2012) The Revolution of Applied Science Institutes Based on the Study of BGI. Science and technology of China BBS, 7-10.

[20] Qian, W. (2011) BGI: The Worldplants of Genes Sequencing. China Newsweek, 65-67.

[21] Zhang, F. (2008) The Process Model Study of the Influence of HRM Practices on the Organization Technology Innovations. Master's Degree Thesis, Zhejiang University, Hangzhou.

[22] Wang, H. (2011) The Study of the Relation between the Market-Oriented and Technology Innovation Models. Reformation and Strategy, 62-64.

[23] Bao, G., Yang, Z. and Xie, Z. (2006) The Structure Analysis of the Small Business Innovation Strategy-Based on the Small Businesses in Zhejiang Province. R\&D Management, 64-71.

[24] Zhao, F. (2012) The Study of the Micro Innovation Characteristics of Companies and the Strength Promotion. Science Study, 141-145. 
[25] Ma, M.Y. (2007) The Analysis of Innovative HR Development and Management. Science and Economy, 46-49.

[26] Xu, G. (2013) The Analysis of the HR Practices under the Innovative Strategy. Science Information of Heilongjiang, 175.

[27] Wang, H. (2011) The Study of the Relation between the Market-Oriented and the Technology Innovation Model. Reformation and Strategy, 62-64+75.

[28] Liang, J. (2013) The Big Situation Directed by the Micro-Innovation. Selling and Market (Management Version), 49-53.

[29] Geng, D. and Fan, Y. (2013) Talking about the Micro-Innovation of Chinese Small Businesses. China's Collective Economy, 37-39.

\section{Submit or recommend next manuscript to SCIRP and we will provide best service for you:}

Accepting pre-submission inquiries through Email, Facebook, Linkedin, Twitter, etc A wide selection of journals (inclusive of 9 subjects, more than 200 journals)

Providing a 24-hour high-quality service

User-friendly online submission system

Fair and swift peer-review system

Efficient typesetting and proofreading procedure

Display of the result of downloads and visits, as well as the number of cited articles

Maximum dissemination of your research work

Submit your manuscript at: http://papersubmission.scirp.org/ 